This is an original manuscript of an article published by Taylor \& Francis in Australian and New Zealand Journal of Art on 14/8/2018 available online at

http://www.tandfonline.com/10.1080/14434318.2018.1481331

\title{
Conflict, Complicity and Ben Quilty's After Afghanistan portraits
}

Kit Messham-Muir

kit.messham-muir@curtin.edu.au

\begin{abstract}
:
Ben Quilty was commissioned by the Australian War Memorial as an Official War Artist in 2011 and sent to Afghanistan for a month as a guest of the Australian Defence Force. $\mathrm{He}$ is one of a new generation of high-profile contemporary artists recently commissioned to create art works about Australia's involvement in current armed conflicts and peace-keeping missions. The works by Quilty, a series of soldier portraits, seek to address the psychological trauma suffered by many Australian troops as the result of their experiences in Afghanistan. Nevertheless, critics such as Rex Butler, and some of the recent commissioned artists themselves, emphasise the potentially fraught negotiation of the role of the artist and the interests of a government institution, suggesting that the work of official war artists is compromised by, or is even complicit with, government foreign policy. Focusing on the work of Ben Quilty, this article addresses some key criticisms of potential conflict and complicity levelled at Quilty's After Afghanistan portraits, and references work by other recent Australian Official War Artists, such as Shaun Gladwell, Lyndell Brown and Charles Green. In particular, this article considers these criticisms through an examination of the aesthetics and iconography of particular Quilty war art works.
\end{abstract}

Keywords: Contemporary art, official war artist, aesthetics, war, Ben Quilty 
For over a century, government museums and memorials in Australia, the United Kingdom and Canada have commissioned artists to create work about the nation's involvement in conflicts through Official War Artist and other schemes that embed artists alongside deployed military units in war zones. ${ }^{1}$ Over the last ten years, the character of these commissioned artists has changed significantly, with high profile contemporary artists now recruited to engage the topic of war with an independence that previous commissioned war artists may have envied. Recent official contemporary war art now embodies diverse and sometimes contentious viewpoints and, in Australia, better represents Indigenous artists and women artists largely excluded from earlier commissions. ${ }^{2}$ Contemporary artists such as Tony Albert (b. 1981), Lyndell Brown (b. 1961) and Charles Green (b. 1953), Shaun Gladwell (b. 1972), eX de Medici (b. 1959) and Ben Quilty (b. 1973) have been embedded with troops as guests of the Australian Defence Force (ADF). And, official war art is now well established within international contemporary art discourse with, for example, the placement on the cover of ARTnews in 2015 of Gladwell's Double Balancing Act (Left) (2010) a key work of his Official War Artist commission, accompanying a feature article discussing Gladwell's official war works alongside non-official war art, such as Richard Mosse's 2010 'Infra' series. Laura Brandon, former Canadian War Museum historian, noted in 2009 that Australia's Official War Artist scheme 'increasingly reflects contemporary artistic practice'. ${ }^{3}$ The work of recent Official War Artists is often edgy, complex and at the centre of global debates in today's contemporary art, while also addressing difficult ethical and political issues such as drone warfare (Gladwell, Australia), the deaths of soldiers (Steve McQueen, UK) and, more recently, soldiers with post-traumatic stress disorder (Quilty, Australia). However, the role of the official war artist is fraught: recent war artists have attracted criticisms that, by taking on the role, they become complicit with the foreign policy interests of the same government that funds their commission. And, in doing so, contemporary official war artists are necessarily ethically compromised. Focusing on the works of Australian Official War Artist, Ben Quilty, this article considers the ways in which the interpretation of 
commissioned contemporary war art is fraught by the complexities of this institutional relationship. It will focus on Quilty's works exhibited together as the After Afghanistan exhibition, which form the mainstay of his commissioned body of works, particularly Captain $S$ after Afghanistan (2012), and will consider some of the key criticisms of these works, mainly in recent criticism by Australian academic art theorist Rex Butler. This article considers aspects of Butler's criticisms by addressing Quilty's works themselves, and takes into account the approaches of other Australian Official War Artists in this new generation.

Official war art began for Australia when Will Dyson (1880-1938) was deployed to the Western Front of World War I with the Australian Imperial Force in December 1916. Although his initial suggestion to be engaged officially as a war artist was rejected, he nevertheless produced sketches in the trenches of France, recording first-hand the experience of the Diggers. ${ }^{4}$ His work then received the attention of Charles Bean, Australian war correspondent and historian, who considered his sketches to be a more truthful depiction than the staged photographs that often emerged from the War. ${ }^{5}$ With Bean's support, Dyson was appointed as Australia's first Official War Artist in May 1917. 6 The role evolved from Dyson's deployment and his successors include George Washington Lambert (1873-1930), Arthur Streeton (1867-1943), Stella Bowen (18931947), and Donald Friend (1915-1989). Other Commonwealth agencies also commissioned artists such as William Dobell (1899-1970) and Herbert McClintock (1906-1985), whose works later came into the collection of the Australian War Memorial (AWM) after it was established in 1941. However, the AWM's Official War Artist scheme eventually became defunct in 1968, struggling to remain relevant in the emerging age of televised war, and due to the alreadyunpopular Vietnam War. Moreover, Official War Artists Bruce Fletcher (b. 1937) and Ken McFadyen (1939-1998) needed to be combat trained for the conditions of Vietnam and willing to fight if required. In 1999, the AWM revived the scheme after a 30-year hiatus with Australia's peacekeeping mission in Timor-Leste, deploying Rick Amor (b. 1948) and Wendy Sharpe (b. 1960), and Jon Cattapan (b. 1956) later in 2008. eX de Medici (b. 1959) was also sent to the Solomon Islands in 2003. This revival of the scheme began to register a substantial rethinking of the role of an Official War Artist since McFadyen's placement in Vietnam-as Ryan Johnston, until recently the Head of Art at the AWM, explains, 'The scheme was revised and expanded in 
1999 by the AWM's then Head of Art, Lola Wilkins, and Director, Major General Steven Gower. Their changes were significant. The scope of the scheme was broadened to include a range of military operations, not just wars, while the artists were given considerably greater freedom than before. ${ }^{7}$ This new approach became clearer following the 11 September 2001 terrorist attacks. Peter Churcher was sent almost immediately in 2001 with the Royal Australian Navy in the Persian Gulf and the Air Force on Diego Garcia. Lewis Miller was sent in April 2003, during the Coalition invasion of Iraq, spending time with the Navy in the Persian Gulf, the Air Force in Dubai, the Army in Doha, and the SAS in Iraq. Involving 43,000 Australian servicemen and servicewomen, Australia's military involvement in the so-called 'War on Terror' was one of its most significant military deployments and, domestically, it was politically contentious. According to Johnston, it was AWM's appointment of Lyndell Brown and Charles Green as Official War Artists in Iraq in 2007 that fully realised the new approach of the scheme: 'a shift to the consistent engagement of artists with a high profile in the contemporary Australian art world. ${ }^{8}$ Brown and Green were followed by Gladwell in Afghanistan and the Middle East in 2009 and Ben Quilty in Afghanistan in 2011. Quilty was, thus, the last of six Australian Official War Artists to be deployed to cover Australia's part in the 'War on Terror', to either Afghanistan, Iraq, or the Persian Gulf. 


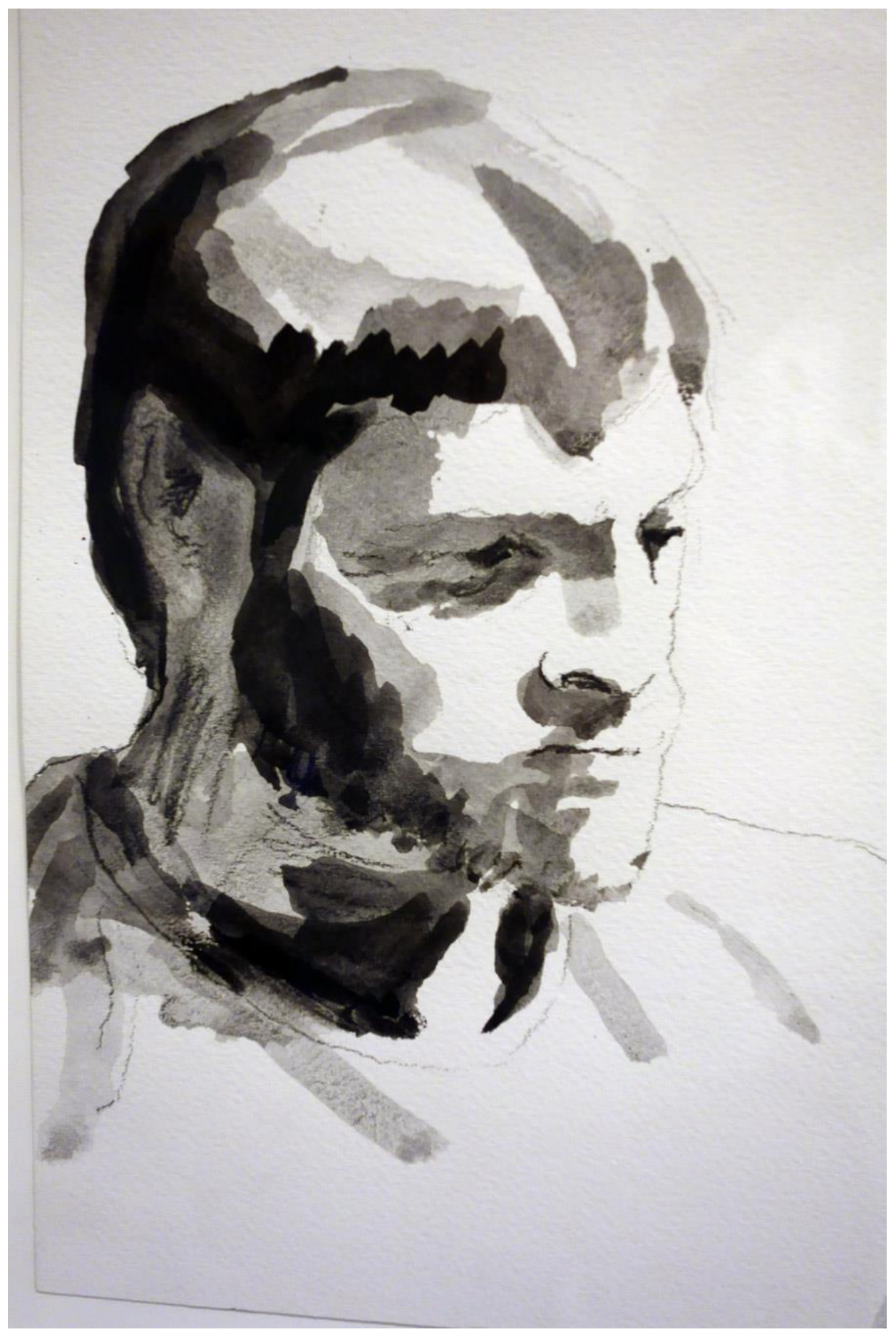

Figure 1. Ben Quilty, Captain M II, Tarin Kot, 2011, pencil and ink wash on paper, $30.4 \mathrm{~cm} \times 23 \mathrm{~cm}$. Collection of the artist. (C) and courtesy of the artist. 


\section{Ben Quilty's After Afghanistan series}

By Quilty's commission in October 2011, Australian troops had been in Afghanistan for ten years, resulting in 30 Australian deaths to that point, of predominantly men in their 20 s. ${ }^{9}$ Quilty had firmly established his practice as a contemporary painter focusing on issues surrounding masculinity in Australian culture. Since emerging in the early 2000s, Quilty's work had addressed the emotional repression of young Australian men and their tendencies towards selfdestructive hedonistic initiation rites, dangerous driving, and drug and alcohol abuse. The prospect of spending time with Australian troops in a war zone seemed to Quilty like a natural progression. He says, 'The opportunity to go and work with these young men in Afghanistan was almost the height of my exploration of the way masculinity plays itself out in our culture.'10 He spent 24 days in Afghanistan, which he found to be 'So far outside of my experience of being human that I really wondered how I would make work about it. ${ }^{11}$ During his time there, Quilty took video, photographs and sketches, mostly at Camp Holland, the Coalition base at Tarinkot, Urōzgān Province. Many of those early pen and ink sketches were the result of live sittings with soldiers, such as Captain M II, Tarin Kot (2011) (fig. 1), and Captain Kate Porter, Tarin Kot (2011). After returning to his studio in the tranquillity of Robertson, country New South Wales, Quilty took several months to process his experience, as he explains:

In the contract, the job is to tell the story of the Australian people on the frontline, so I really just became engaged with those people ... pulling those men into the studio when they returned from Afghanistan just felt quite natural. It was the right thing to do. And some of the work has become quite dark because of their experience-it's a cliché from the Vietnam War-that they then suffer the emotional effects from being exposed to the things that they're exposed to, and exposed to a lot more than I would ever had imagined. They're exposed to some very confronting things. So, to then watch them try to struggle to come back and fit in, and drop, fall, crashing down to the earth with posttraumatic stress disorder is very crushing and confronting. ${ }^{12}$ 
The core of Quilty's commission became the emotional and psychological impact of Australia's military involvement in Afghanistan on the returning soldiers, many of whom now suffer from post-traumatic stress disorder and depression, sometimes leading to suicide.

The central theme of post-traumatic stress disorder in Quilty's commissioned works brought him into direct conflict with elements of the Australian Defence Force, with which he had travelled to Afghanistan as a guest. Two episodes of ABC television's documentary series Australian Story focused on Quilty's Official War Artist work: the first episode, War Paint, was broadcast on 3 September 2012, with a second episode on 25 March 2013, following up on the attention Quilty's After Afghanistan exhibition was receiving as it toured Australia. In his introduction to the second episode, titled On The Warpath, Craig Reucassel said, 'six months on, Quilty has gone from official artist to angry advocate. He wants better treatment for Australian soldiers, who he says are still suffering from their time in the war zone. ${ }^{13} \mathrm{At}$ a panel discussion hosted by the National Art School Gallery on 20 March 2013, which included Australian Official War Artist Wendy Sharpe and journalist Scott Bevan, Quilty was swingeing in his criticism of the Defence Force. Quilty's narrative of trauma, it seemed, was unpopular with 'the brass': 'The Australian Story, which ran this year, was one of the low points of my existence living in this democracy. The way the Defence Force acted, and the way they tried to stop these young men talking about post-traumatic stress disorder, I'm not going to forgive them in a hurry. ${ }^{14}$ In the later episode of Australian Story, Quilty continued to criticise his erstwhile ADF hosts, as well as Veterans Affairs, the Australian government ministry that oversees the AWM, for their lack of action in addressing returning soldiers suffering PTSD: 'I had no idea the ADF worked like this ... It has been a real eye-opener and at times a very sad thing to witness. There is [sic] two big worlds between what the generals say is happening and what is really happening. They're not the same. ${ }^{\prime 15}$ By bringing intense public attention to PTSD, depression and suicide, Quilty believed he may actually have threatened the future of the AWM's Official War Artist scheme. ${ }^{16}$ 


\section{Rex Butler's criticism of Quilty's After Afghanistan series}

One of the most comprehensive criticisms of Quilty's war art comes from the influential critic Rex Butler, in two iterations of 'Ben Quilty: The Fog of War'; the first, a paper delivered at The Finest Art Seminar Series Tonight on 4 April 2015, in Brisbane, Australia; ${ }^{17}$ the second, a published article in Intellectual History Review in June 2017. ${ }^{18}$ In these, Butler provides some of the most recent and comprehensive critical engagements with Quilty's war art, which consider 'the popularity for both the public and critics for Quilty's war paintings,'19 demonstrated by the public appeal by the Queensland Art Gallery for the purchase and acquisition of Sergeant $P$ After Afghanistan (2012) (fig. 2). ${ }^{20}$ Indeed, in his 2015 paper, Butler posits the overwhelmingly positive reception of Quilty's work with a 'nationalist group-think' amongst Australian critics. ${ }^{21}$ Butler argues that both Quilty and Gladwell are relatively rare amongst their generation of artists for making 'Australian art', 'At a time when many young artists here [in Australia] seek to make art that could come from anywhere, thereby avoiding the accusation of nationalism' ${ }^{22}$ Indeed, it is the distinctive Australianness of Quilty's iconography (Captain Cook, Toranas, budgerigars) and his 'bogan'23 (unsophisticated Australian working class) adolescent biography, Butler supposes, that led to his commissioning as an Official War Artist: 'The Australian War Memorial commissioners - in an at once innovative and conservative gesture-must have hoped that he would bring the same laconic, populist and anti-elitist attitude to the depiction of the lives of young soldiers'. ${ }^{24}$ Quilty's critical and popular reception, argues Butler, is a result of the paintings' ostensive aim to create an empathic connection between Australian audiences and the traumatic experiences of the soldiers they depict. However, he consistently argues, 'The real experience of the work is an empty expressiveness, the signs of expressivity but without anything actually being expressed. ${ }^{25}$ In other words, the paintings' expressionistic aesthetic actually conveys nothing of the trauma experienced by their sitters, yet it allows audiences to go-through-the-motions by playing-out the expressionist trope of externalising inner psychological and emotional states. 'Not only do we not come to know what the soldiers went through,' Butler argues, but 'we ultimately do not want to know; and in fact what the paintings offer the viewer (and hence their public success) is a way of avoiding any real encounter with the outcome of war, the public performance of responsibility without any of its 
real-world consequences. ${ }^{26}$ Put another way, perhaps, by engaging with the aesthetic rhetoric of Quilty's expressionist painting style, and its gestures of violence, trauma, and emotion, audiences are excused from dealing with the actual violence, trauma and emotion experienced by his sitters.

For Butler, moreover, there is a more problematic political end to Quilty's 'performance' of trauma, beyond potential ersatz empathic connections: by suggesting that we might get to know these soldiers and their trauma through these paintings, "we might somehow explain the war, give it a justification it might not have otherwise'.${ }^{27}$ Rather than confronting the state, whose political decisions led to the trauma experienced by his sitters and whose military establishment he accuses of neglecting that trauma, Quilty's paintings are potentially complicit with the conservatism of these state institutions. In his seminar paper, Butler reinforces this suggestion through comparative analyses of different soldiers' portraits: 'in a very traditional way, Quilty produces-and this is, I think, very telling-more detailed renderings of older and more higher-ranked officers ... they're depicted much more 'realistic', as though they deserve more attention, rather than the younger and more junior soldiers. ${ }^{28}$ Quilty's soldier portraits, thus, are not only complicit with the military hierarchy and the machinery of state, but his expressionistic tropes, such as the 'inexplicable miasmatic cloud' in Sergeant $P$, engage a 'complicit vagueness between artist and spectator', 'a shared complicity, after all, that reassures us that we do not really have to do anything about Sergeant $P$, do not really have to get to know him, as long as we buy the picture. ${ }^{29}$ His 2017 article is less interrogative of Quilty's intentions, rather indicting 'the ideology of our time', of 'solicitation at a distance or care without responsibility'. ${ }^{30}$ In both paper and article, however, Quilty's aesthetic gestures, his 'empty expressiveness, the signs of expressivity', are implicated in creating an agreeable mask for the tacit acceptance of the trauma the works purport to address:

We just abstractly have to feel or sympathise with them [traumatised returned soldiers], and that is enough. (This is, moreover, the exact correlate of the condition that Quilty says he is fighting against: that our rehabilitation services for returned soldiers are not 
enough for them, but merely enough for us to believe that we are doing enough for them. $)^{31}$

Read from that position, Quilty's After Afghanistan portraits could be seen less as a critical broadside on the uncaring machinery of government, and its ethical failure to act adequately and appropriately to the wellbeing, health, and safety of its troops, and more as a performance of dissent that, whether by design or otherwise, is 'empty' (merely aesthetic, perhaps) and thus destined to be neutralised, to be absorbed and have negligible political impact.

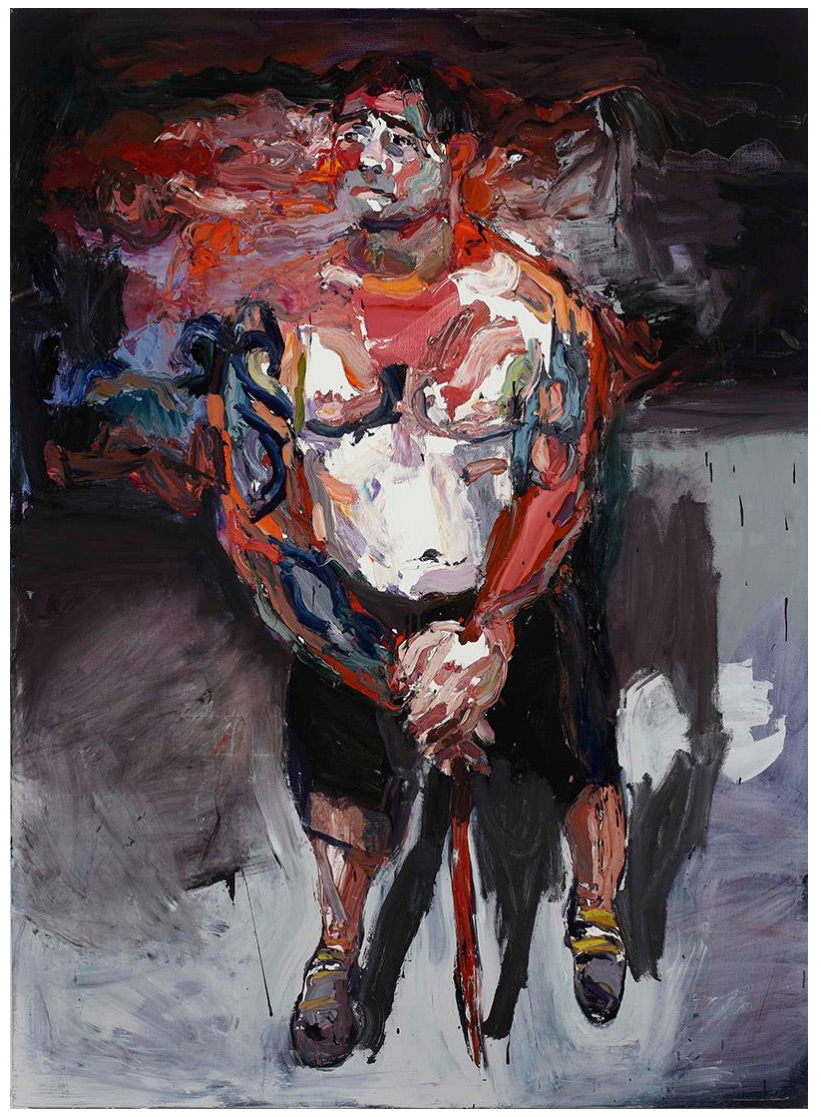

Figure 2. Ben Quilty, Sergeant P. After Afghanistan, 2012, oil on linen, $190 \mathrm{~cm} \times 140 \mathrm{~cm}$. Image courtesy of Queensland Art Gallery/Gallery of Modern Art.

Indeed, despite Quilty's fears in 2013 that his criticisms of certain branches of the Australian government may threaten the future of the Official War Artist scheme, ${ }^{32}$ the scheme has not only continued, with Tony Albert (b. 1981) following shortly after Quilty, but the AWM has commissioned further work from Quilty-a series of portraits of the families impacted by 
Australian soldiers' deaths or PTSD-further reinforcing the contentious narratives of trauma. Similar to Butler's criticisms of Quilty, Julian Stallabrass, speaking on a symposium panel with Gladwell in 2016, questioned the capacity of official war art to critically attack the state. Indeed, Stallabrass suggested that state authorities may actually welcome the critical stance taken by the war art they commission because it 'somehow serves the machine'. ${ }^{33}$ In essence, the house always wins; and regardless of the intentions of any official war artist, they are fundamentally complicit in their participation of the government's disingenuous performance of liberal democracy, implicated in manufacturing dissent that ultimately reinforces government foreign policy as, Butler says, 'an official part of Australia's military campaigns'. ${ }^{34}$

\section{Compromise and Negotiation}

Neither the AWM or the Australian Defence Force place any conditions on the subject matter contemporary Official War Artists can deal with. According to Quilty, Steve Gower, the then AWM Director, told him, 'you say whatever you want. You're in a position no one else is in, if you tell a negative story, we'll back you up. ${ }^{35}$ As Johnston, then AWM's Head of Art, notes, contemporary Official War Artists enjoy 'considerably greater freedom than before'. ${ }^{36}$ 'As a government-funded institution', says Quilty, 'for them to send us there and do that, I think, it's a healthy sign of a good democracy. ${ }^{37}$ However, the practicalities of embedding artists with troops in war zones tend to set conditions of their own. The Imperial War Museum (IWM) commissioned McQueen in 2007, who was briefly deployed in Afghanistan and, he says, was 'not allowed to go anywhere' while he was embedded with British troops in the Iraqi city of Basra. According to The Guardian's report at the time, he was 'told that if he wandered off on his own, he'd get no support'. ${ }^{38}$ While in Kuwait, Gladwell did wander off to the edge of the base to take photographs and was apprehended by guards for not having the appropriate paperwork. Stepping outside of the bounds of the Coalition base placed Gladwell in real danger, from Coalition troops as much as any local insurgents. ${ }^{39}$ Darren Jorgensen compares Quilty's and Gladwell's experience of Australian military bases in Afghanistan with the experience of George Gittoes, who has forged deep connections with locals in Afghanistan and has run a 
studio for Afghan artists in Jalalabad since 2011, noting that the Official War Artists 'made work within military bases sealed-off from the rest of Afghanistan', ${ }^{40}$ and that 'These bases are neither Afghanistan, nor are they the country of the occupier. ${ }^{\prime 41}$ Embedded artists are entirely dependent on the troops for survival and, as Stallabrass says of civilian journalists embedded with US troops in Iraq, 'they were generally very grateful for the access to spectacular stories, admiring of their protectors, and appreciative of the troops various travails'. ${ }^{42}$ The access granted to embedded artists can itself engender a sense of privilege: Quilty recounts being 'invited into the Special Forces headquarters' in Afghanistan and introduced to the Commander, while even his ADF armed escort was not allowed access. ${ }^{43}$ Stallabrass suggests this sense of privileged access and gratitude can compromise the criticality of the embedded civilian. ${ }^{44}$ And, of course, living and working with troops over several weeks and sharing intensely stressful life-and-death experiences with them tends to foster a strong identification. ${ }^{45}$ So, while journalists embedded with US troops in the Iraq War were largely uncensored, they could only ever produce 'a narrow view of the war ... one focused on the experiences of the troops. ${ }^{\prime 46}$ Moreover, the specific remit of AWM's Official War Artist commission is to create work about the experience of Australian troops. So, while at a personal level Gladwell was politically opposed to Australia's involvement in the 'War on Terror', he had 'been asked to work with a community of people and an organisation.' ${ }^{47}$ To enter the commission with an explicit position against the war was indeed possible, but pragmatically, working directly with Australian soldiers, it 'certainly wouldn't have been very productive over there. ${ }^{\prime 48}$ So, while the AWM adopts an unequivocally hands-off approach, the very nature of embeddedness inevitably limits perspective and determines the ideological frame through which Official War Artists see the war. The kind of nuanced Afghan voice incorporated into Gittoes' work is simply not possible; if narratives of trauma are told, they are of the trauma experienced by Australian troops; the artists come away 'with an incredible respect for the men and women' they met, as Brown says, ${ }^{49}$ and 'By the end of it,' says Quilty, 'I have made life-long friends with some of those people. ${ }^{50}$ 


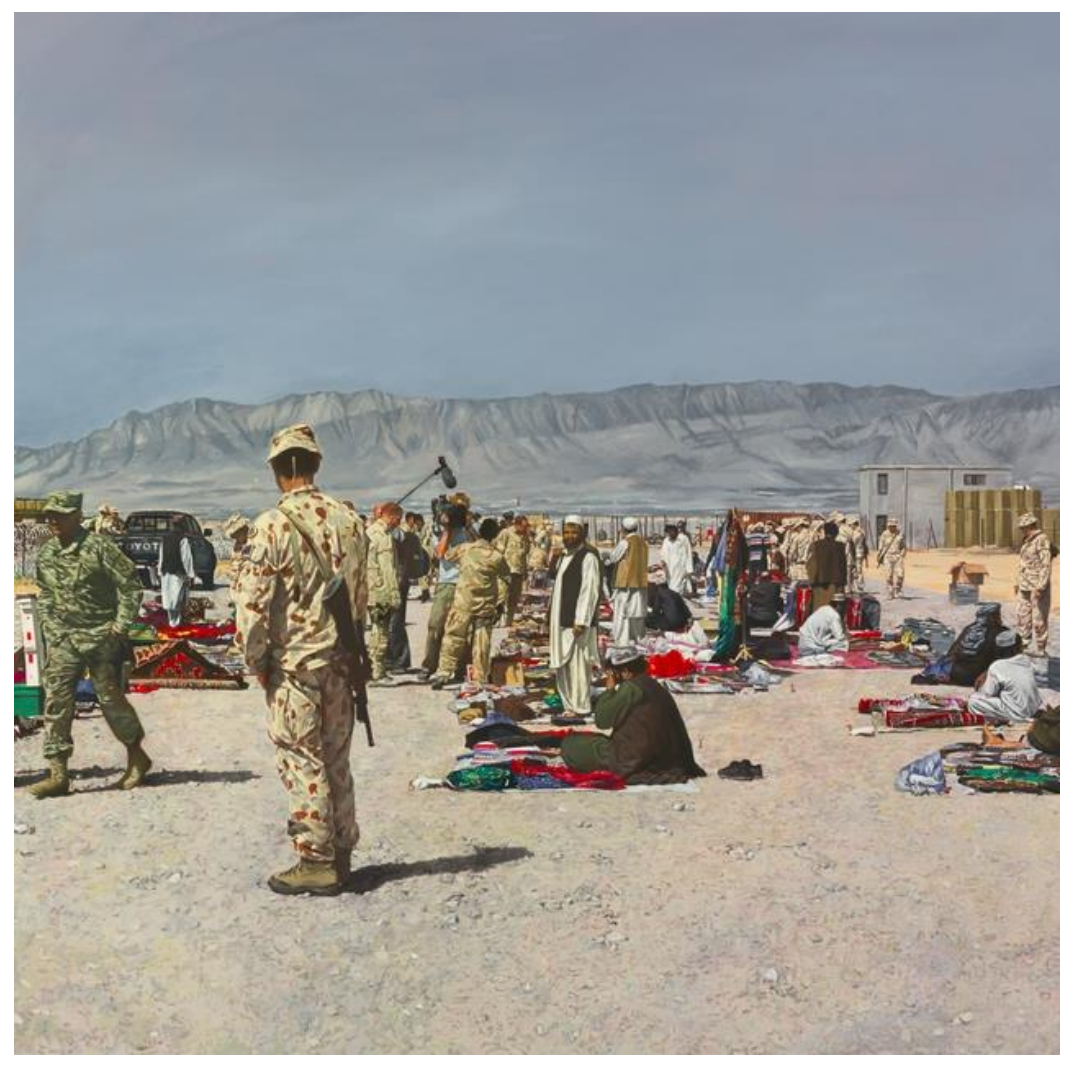

Figure 3. Lyndell Brown and Charles Green, History painting: market, Tarin Kowt, Uruzgan province, Afghanistan, 2008, oil on canvas, $121 \mathrm{~cm} \times 121 \mathrm{~cm}$. Image courtesy of the Australian War Memorial collection.

Thus, the conditions of the Official War Artist commission result from a complex array of institutional, interpersonal and social pressures, security practicalities and parameters in the field, and all the compounding synergisms between, which surely mount up and substantially influence the kinds of works that are likely to emerge. Any close consideration of contemporary official war art must acknowledge these inherent conditions and recognise the ways in which these necessarily delimit what it is possible to say and to not say. 'It's not a compromise,' Gladwell says, 'but it's a negotiation. ${ }^{51}$ Brown and Green acknowledged and accepted the practical conditions surrounding the commission as a parameter that, Brown says, 'wasn't really a constraint. It was more to do with calibrating. ${ }^{52}$ Indeed, Official War Artists have responded to these limitations by making clear their awareness of the ideological context into which they were placed and the inherent limitations of that. For example, Brown and Green's History Painting: Market, Tarin Kowt, Uruzgan Province, Afghanistan (2008) (fig. 3), knowingly makes- 
strange the Afghan traders and their local wares within the boundary of the Australian camp, under an imposing Afghan mountain range, consciously incorporating the ghosts of nineteenth-century Orientalist paintings' ${ }^{53}$ Many of their photographic images emphasise the thresholds of the base; many are of perimeter posts and Hesco bastion walls, essentially large utilitarian mesh sand bags, which look as out of place as the desert camouflage worn by the Australian soldiers. Seeing across protective barriers is a theme present throughout Brown and Green's body of war art work - the limitations become much of what these works address. As with Brown and Green's point of view, Quilty's perspective remains always aligned with the perspective of the Australian troops, on the inside of the thresholds literally between 'us' and 'them'. In this respect, Stallabrass, Butler and others rightly suggest that the conditions of these commissions circumscribe what is possible through the work. It does not follow, however, that the work created within these conditions is necessarily politically neutralised or complicit; or that drawing upon a stylistic expressionism, this aesthetic treatment of war necessitates a critical unhinging from the political, the mere performance of responsibility.

\section{'Empty expressiveness' in Quilty's After Afghanistan series}

Butler's criticisms of Quilty's After Afghanistan portraits are drawn from close analysis of the paintings within their broader discursive context and at an aesthetic level. His core conclusion is that Quilty's war art works convey 'an empty expressiveness, the signs of expressivity but without anything actually being expressed. ${ }^{54}$ Certainly, a lot has been said of the works, and for the works, creating for them a set of statements that speak in their place: AWM curator Laura Webster says of Quilty's portraits of Air Commodore John Oddie, 'The portraits reveal a man returned from war and its burden of responsibility, exhausted emotionally and mentally, and his progress towards a more positive view of life and of himself as a survivor'; 55 Makani Luske says that Captain S after Afghanistan, and other works, 'give a first-hand illustration of what the soldiers experienced in Afghanistan'; 56 and John McDonald states, 'no-one has captured the underlying trauma of active service so vividly. ${ }^{57}$ Certainly, these and other claims for Quilty's portraits say much more than the paintings actually show. Indeed, it is important to take a 
closer look at Quilty's paintings themselves, as Butler does, to consider what they are made of visually; to ask what they do show, and consider the ways in which they show it.

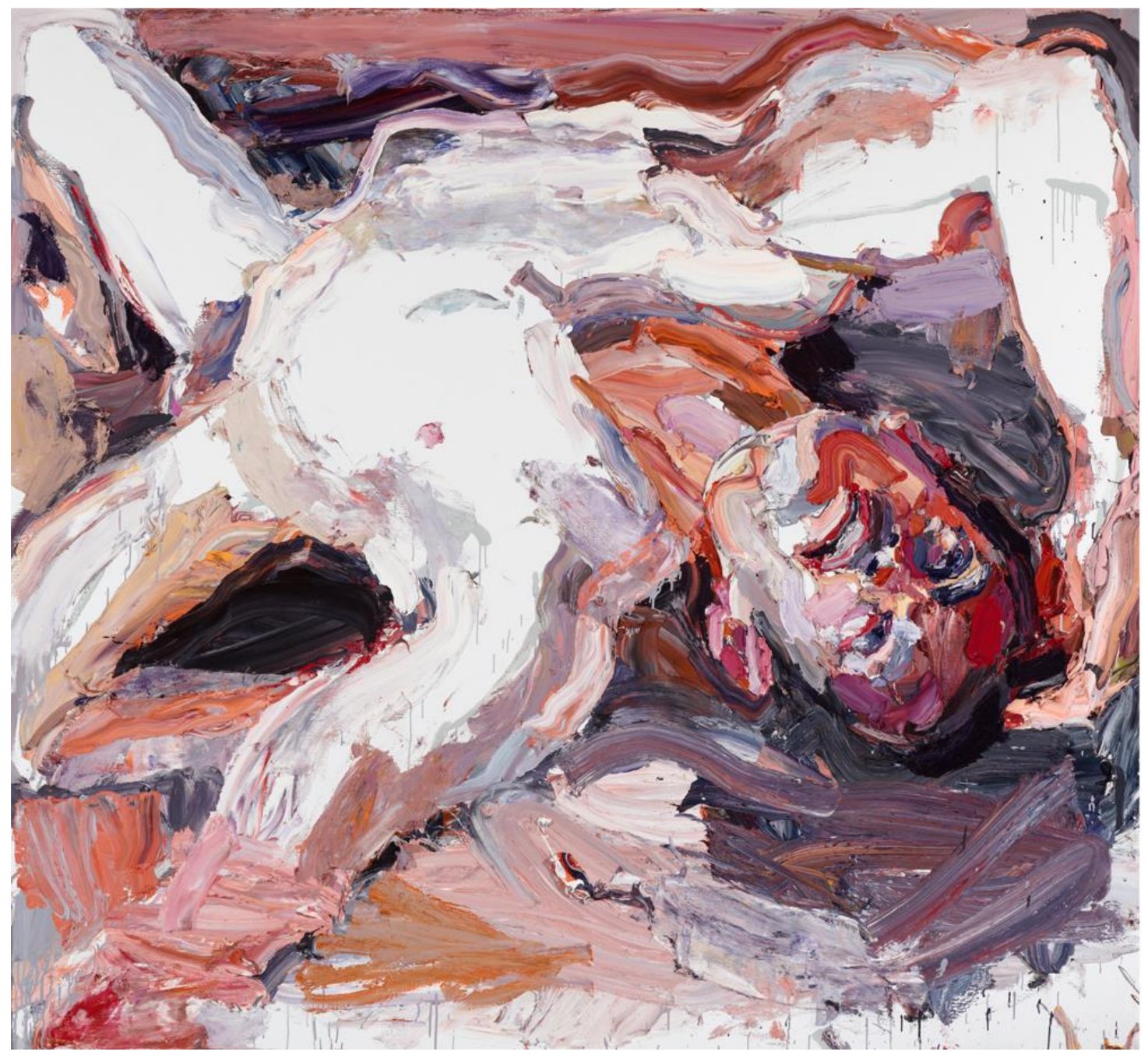

Figure 4. Ben Quilty, Captain S after Afghanistan, 2012, oil on linen, $210 \mathrm{~cm} \times 230 \mathrm{~cm}$. Image courtesy of the Art Gallery of New South Wales.

Captain S after Afghanistan (2012) (fig. 4), was one of the first studio paintings to emerge publicly from Quilty's commission when it was short-listed and exhibited at that year's Archibald Prize. ${ }^{58}$ The sitter, Captain S, is a member of Australia's Special Forces (hence his anonymity), and had recently been wounded in battle in Helmand Province, Afghanistan. Captain S says, 'The pose actually reflects a circumstance on an operation where I was hiding behind a wall ... We were stuck behind cover, being constantly engaged by the insurgency, and 
eventually we withdrew under the protection of darkness. ${ }^{59}$ He spent eighteen hours taking cover behind a small mud-brick wall from constant fire from Taliban fighters, lying face-up, strained uncomfortably across communications equipment strapped to his back, while he coordinated the medical evacuation of a wounded soldier. ${ }^{60}$ The pose in the painting was chosen by Captain S, and Quilty chose his sitter to be naked, 'showing not only his physical strength but also the frailty of human skin, suggesting the darkness of the emotional weight of the war.' ${ }^{61}$ All of his large soldier portraits are similarly naked, to 'tear away the uniform and the bravura of masculinity and the threatening nature of their uniform, and see their soul, and see the flesh that's injured by bullets and shrapnel'. ${ }^{62}$ Captain S after Afghanistan is a $210 \mathrm{~cm} \mathrm{x}$ $230 \mathrm{~cm}$ canvas, rendered in Quilty's signature loose impasto style. The form of Captain S's body is arranged across the nearly-square plane, largely defined by painting-in the negative space surrounding him, applied in thick, mostly left-to-right, palette knife strokes of purples and reds, with more minor strokes of complementary colours. The soldier's naked body is mostly depicted by large areas of unpainted gessoed canvas, with the extremities of his limbs painted in lighter rough strokes of pink and red. The body is on its back, contorted, fitting tightly into the picture plane in a thick ' $X$ '-shape, with the knife strokes of the sanguine head on the lower right of the canvas applied in shorter and more detailed bloody red and purple. Captain S is posed with his right arm above his head, his left arm is indistinguishable beyond a point near the elbow. The upper edge of Captain S's body is similarly indistinct. Overall, the pose resonates in a skewed way with a Renaissance pieta or, as Andrew Yip notes more specifically, Rayner Hoff's Sacrifice (1934), the sculptural centrepiece of Sydney's ANZAC Memorial in Hyde Park, which also depicts a naked convex male body lying on his back: 'Quilty's focus on the individual, shorn of heroic symbols, reclaims the figure from spiritual allegory to that of tribute to the soldier's humanity.' 63 This gestural trope is repeated in various ways throughout Quilty's After Afghanistan series: Trooper M, after Afghanistan; Troy Park, after Afghanistan, no. 2; Trooper M, after Afghanistan, no. 2 (fig. 5); and Lance Corporal M, after Afghanistan; (all 2012). As Butler notes, even the abstracted form of Tarin Kot (2012), which he interprets as an 'explosion', 'is even posed like one of the soldiers: spreadeagled, multi-limbed, seemingly on its back.' $^{64}$ 


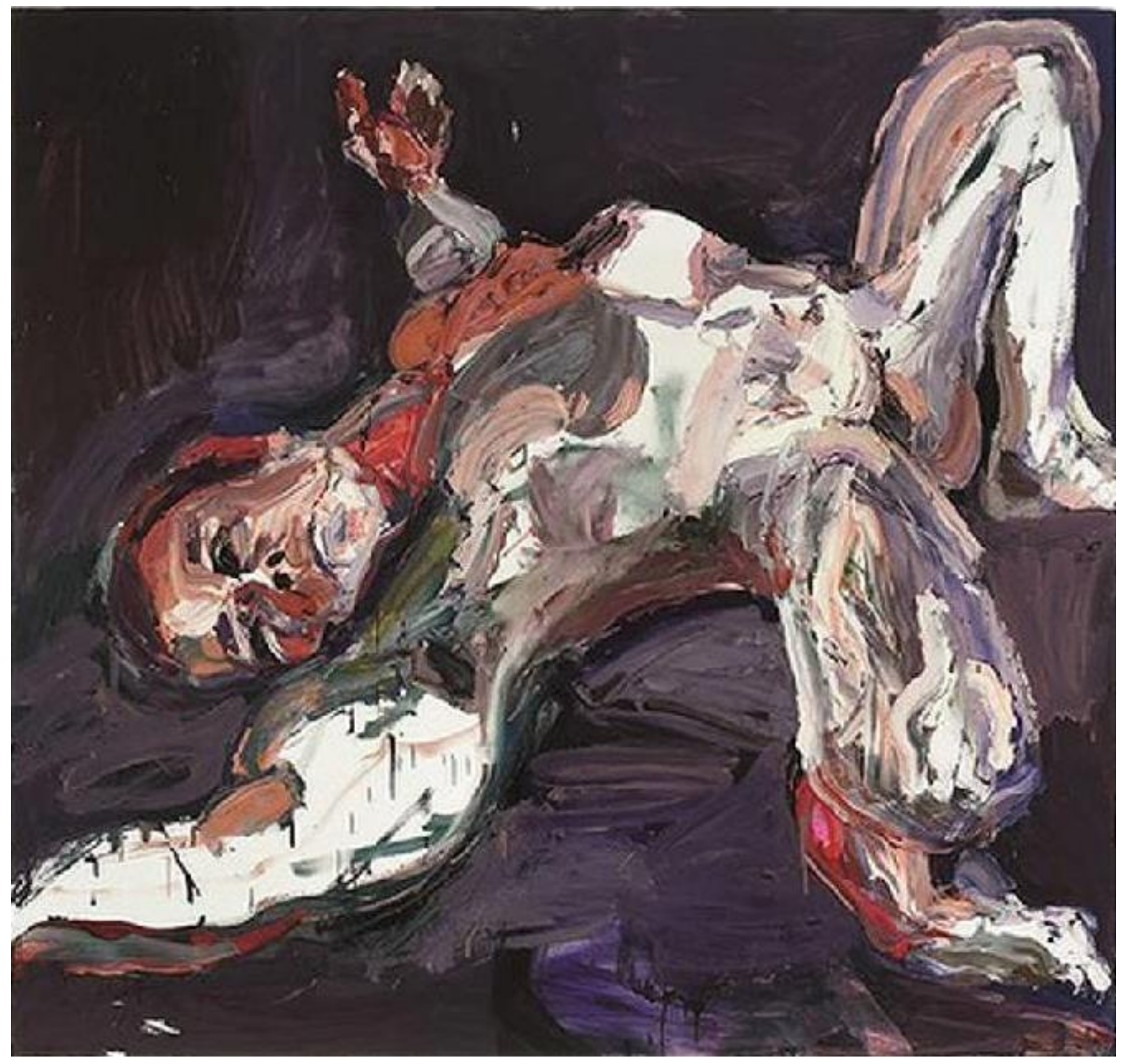

Figure 5. Ben Quilty, Trooper M, after Afghanistan, no. 2, 2012, oil on linen, $170 \mathrm{~cm} \times 180 \mathrm{~cm}$, collection of the artist. (C) and courtesy of the artist.

While the After Afghanistan series as a whole is described as portraits, ${ }^{65}$ many like Lance Corporal M, after Afghanistan and Captain S after Afghanistan are nude life paintings, with the subjectivity of the sitter masked by their anonymity and their pose. They are partial portraits, whose outlines in the image are often indeterminate and fragmented, breaking the boundaries of subject and background. While the portraits are said to 'show' psychological trauma, as we have seen, they may more accurately be said rather to 'enact' trauma through a set of aesthetic 
un-portrayals. That is, the works themselves make no clear didactic statements of their own; rather, what they do 'say' operates on an affective level, through their aesthetics and iconography. More specifically, rather than showing trauma in some representational or allegorical register, these portraits convey the partial presence of their subjects, whose contours are continuously compromised by their indeterminate outlines and particularly the complication of subject and background. Captain S after Afghanistan is a missed portrait, even in the anonymity of its title. Indeed, it is this painting's slurred articulation-the very fact that it does not, and cannot, show trauma or exhaustion-that opens a space for disturbance within what is, importantly, a semi-abstract painting. Taking from Georges Didi-Huberman's playful supposition that Tony Smith's cube sculptures might contain something of 'an equivocal surplus that resists the objectifying gaze', Vlad lonescu says that 'Symbolisation occurs when the mind capitalizes on the surplus of presence that it desires but [that] it does not have. This notion therefore denotes the most common human experience, the confrontation with something that is either absent or only partially present, something that, in any case, is not yet consumed or fixated.' ${ }^{66}$ In its slurred strokes, Captain $S$ after Afghanistan gives us an equivocal surplus that resists the subjectivising gaze. Or, put simply, the subjectivity in this portrait stalls, suspended by elements of abstraction throughout the image. Indeed, like other After Afghanistan portraits that are arguably more successful, Captain S after Afghanistan complicates the boundaries of its figurative body with abstraction. 


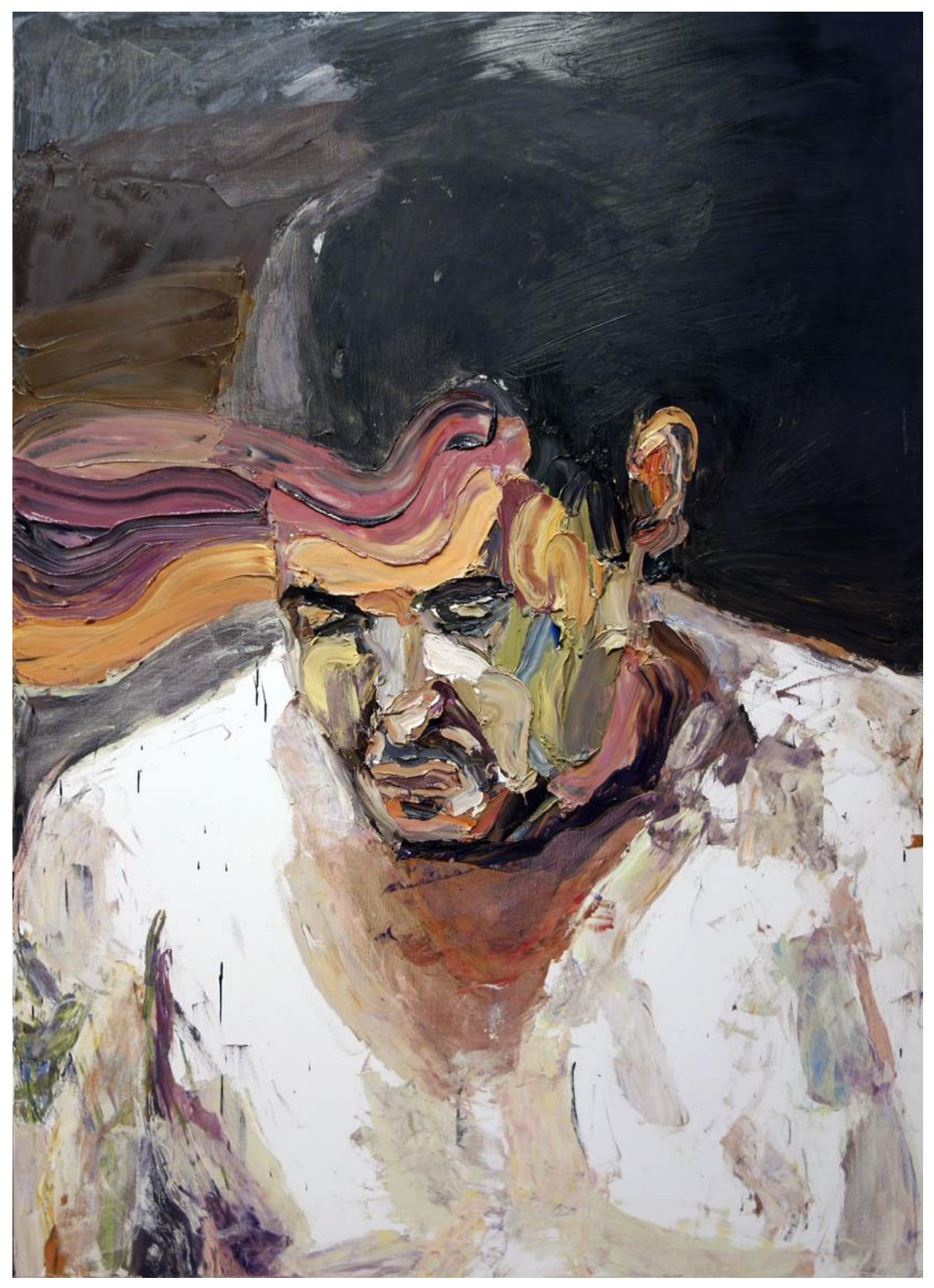

Figure 6. Ben Quilty, Troy Park, after Afghanistan, 2012, oil on linen, $190 \mathrm{~cm} \times 140 \mathrm{~cm}$, collection of the artist. (C) and courtesy of the artist.

This is quite different from other After Afghanistan works that are arguably less successful, in which Quilty deliberately attempts to represent trauma through abstraction, such as with the 'miasmatic cloud' ${ }^{67}$ of Sergeant $P$, after Afghanistan (2012) or in the crimson strokes from the head in Troy Park, After Afghanistan (2012) (fig. 6), found on the cover of the exhibition catalogue and much of the publicity material. Kandahar (2011) (fig. 7) depicts a formless dark 
scrambled mass at the centre of the picture, against a loosely rendered landscape, which Butler interprets as the tangle of a car bomb caught in its moment of disintegration. ${ }^{68} \mathrm{~A}$ similar formless mass, rendered as though the negative of Kandahar, is found on the right panel of Trooper Daniel Spain, Tarin Kot (2012). As Butler points out, Quilty seems to intend these erasures to be both 'the "objective correlate" of the sitter's mood', 69 and part of 'Quilty's implicit thinking of the limits of representational painting in its attempt to render the real' ${ }^{70}$ For Butler, Kandahar fails because, comparing it to Gerhard Richter's Table, 1962, in its use of the incompatible styles of abstraction and representation it apparently fails to maintain both tension and coherence. ${ }^{71}$ Indeed, Kandahar is perhaps the weakest work in the After Afghanistan series; however, I would attribute this to the loose resemblance of the formless mass to a skull, which pushes it towards the realms of allegory. Unlike the slurring in Lance Corporal M, after Afghanistan and Captain S after Afghanistan, the more deliberate indistinct masses in Kandahar and Trooper Daniel Spain, Tarin Kot are theatrical, even melodramatic, in their over-determined allegorical formlessness. If these are flawed as works, it is perhaps in this allegorical dramatisation of trauma, rather than their failure to maintain tension and coherence where 'the great German painter' succeeds. ${ }^{72}$ Rather, this 'failure' is exactly the point at which Quilty's more successful paintings operate aesthetically as works of trauma. While Kandahar is a seemingly self-conscious attempt to represent non-representationality, to articulate inarticulation, the more-successful works, such as the nearly completely abstract work simply titled Tarin Kot (2012) (fig. 8), come at their inarticulation from the opposite direction, by failing to cohere as a representational image. Tarin Kot appropriates the colours and morphologies of the full body portraits-Trooper M, after Afghanistan; Troy Park, after Afghanistan, no. 2; Trooper M, after Afghanistan, no. 2; and Lance Corporal M, after Afghanistan; (all 2012)-but does not reach figuration. In the context of these portraits and its aesthetic similarities, Tarin $K o t^{\prime}$ s incoherence enacts the very disintegration Quilty contrives to deliberately generate in Kandahar. Captain S after Afghanistan enacts a similar disintegration to Tarin Kot. In its semiabstract aesthetic incoherence, it does not transcend a polemical use of contradiction between the figurative and abstract, depicting its subjects through a tense and fragmented aesthetic. 
Thus, it is not a painting 'about' trauma; rather, it enacts a trauma. It is traumatic in its incompleteness, in its incoherence.

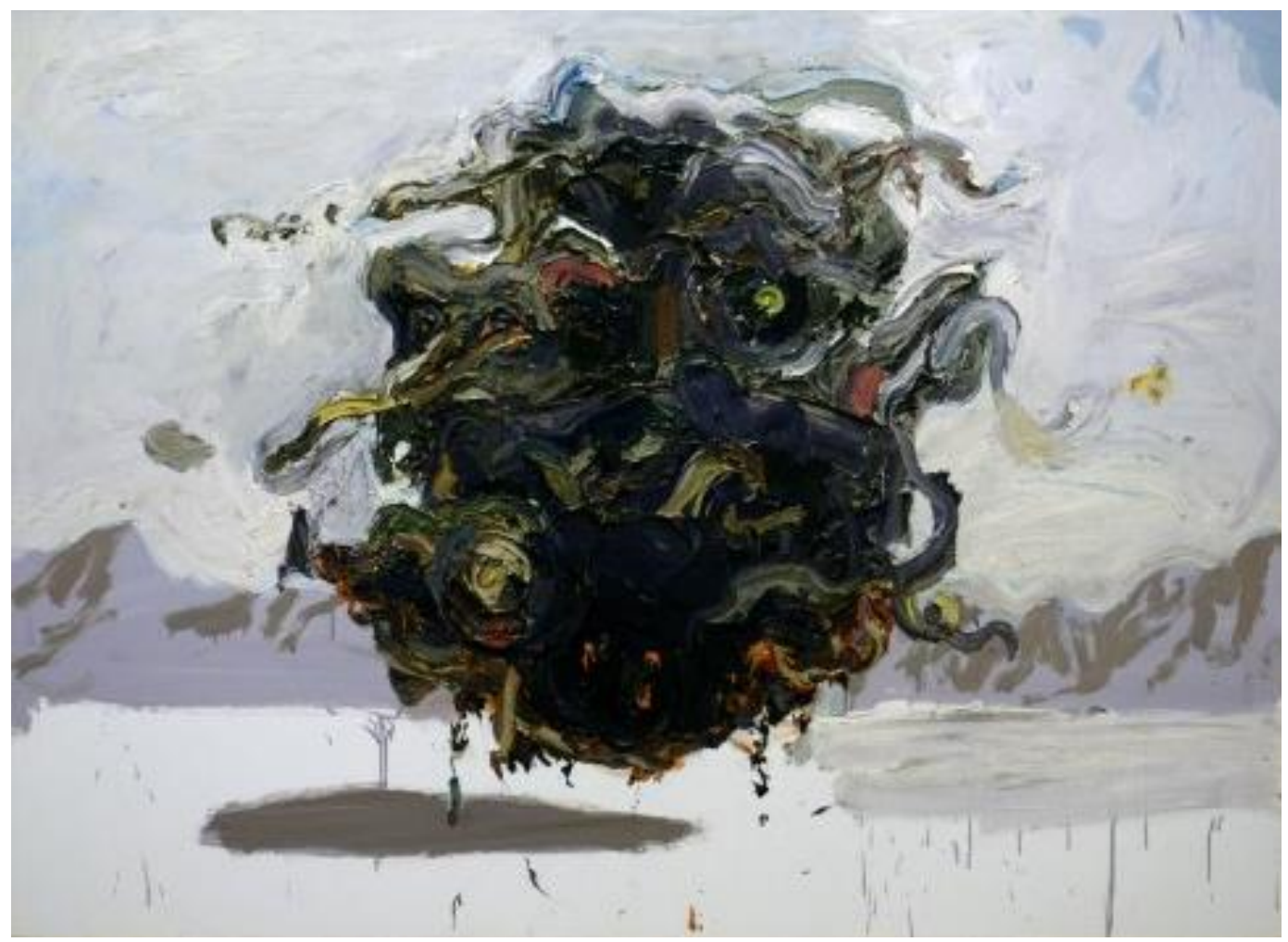

Figure 7. Ben Quilty, Kandahar, 2012, oil on linen, $140 \mathrm{~cm}$ x $190 \mathrm{~cm}$. Image courtesy of the Australian War Memorial collection. 


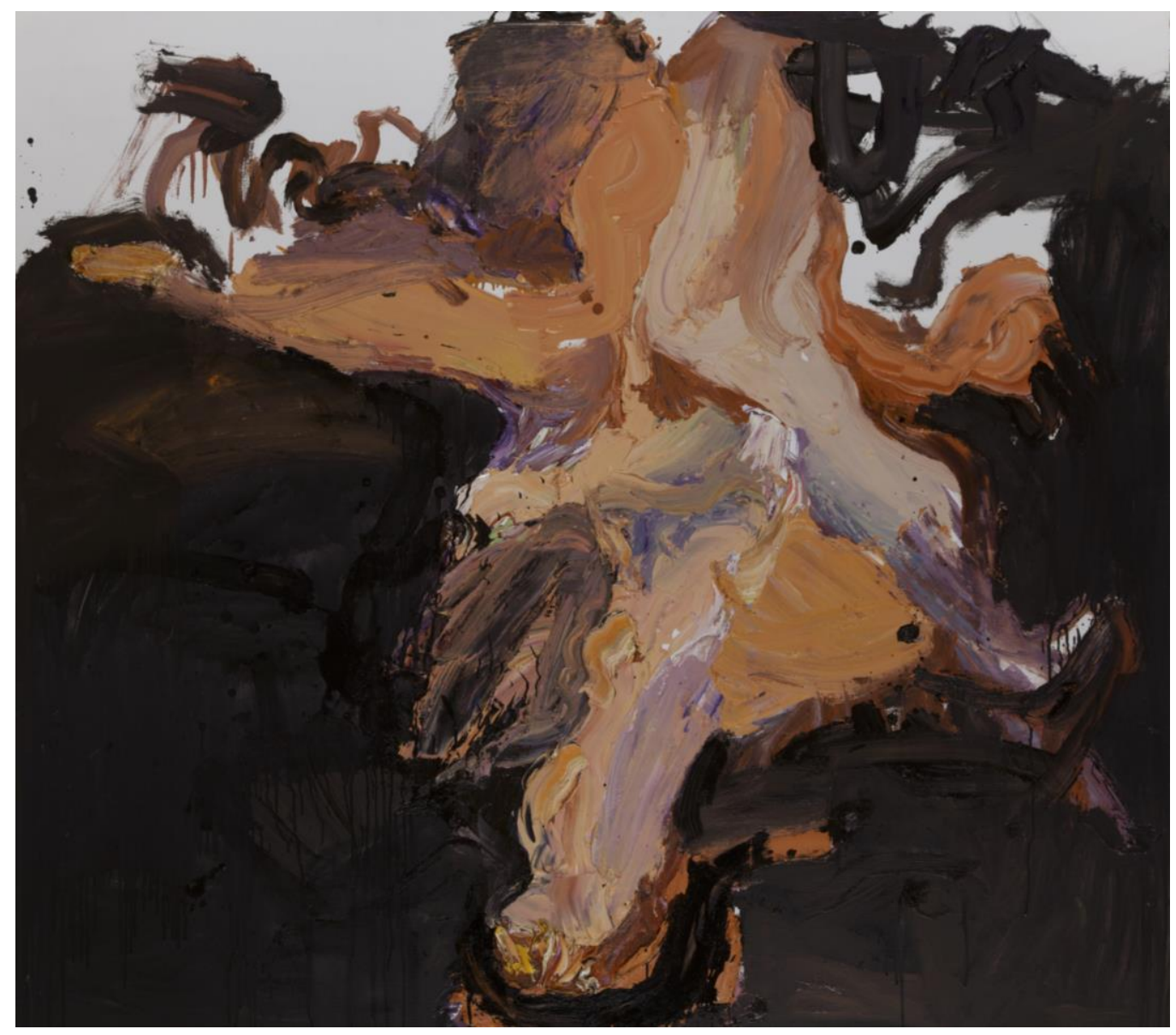

Figure 8. Ben Quilty, Tarin Kot, 2012, oil on linen, $150 \mathrm{~cm} \times 170 \mathrm{~cm}$, collection of the artist. (C) and courtesy of the artist.

At the same time, Captain S after Afghanistan is figurative enough to draw upon a language of bodily gesture that is perhaps not universal but is certainly art historical. As mentioned earlier, Yip notes that Captain S's pose echoes Hoff's Sacrifice, the centrepiece of Sydney's ANZAC Memorial. ${ }^{73}$ For an Australian audience, possibly for Quilty in composing the painting, or possibly for Captain S in choosing his pose, Hoff's Sacrifice feeds into the iconology of Captain S after Afghanistan. On a larger art historical mapping, the gesture of the arm raised above the head brings to mind Aby Warburg's 1909 analysis of the work of Albrecht Dürer, which focuses on the 'emotive gestural language' of Death of Orpheus (1494) (fig. 9). ${ }^{74}$ Warburg argues that the pose of Dürer's Orpheus 'stems from some lost, antique image of the death of Orpheus or Pentheus. Its style is directly informed by the emotive gestural language defined by Greece for this same tragic scene. ${ }^{75}$ Versions of this gesture are found in Warburg's collection of studied 
images of visual phenomena, the Mnemosyne Atlas, particularly on Panel $70 .{ }^{76}$ Warburg built his Mnemosyne Atlas to give visual sense to his studies in iconology, 'which called for art to be analyzed in the context of other cultural phenomena and through the comparison of visual forms. ${ }^{177}$ The pose of Dürer's Orpheus is, for Warburg, Pathosformel, an emotionally charged visual trope ${ }^{78}$ the 'indissoluble intertwining of an emotional charge and an iconographic formula in which it is impossible to distinguish between form and content' ${ }^{79}$ This idea has been taken up more broadly by theorists in recent years, ${ }^{80}$ extending from the affective turn of the early 2000s and the continued interest in the emotional dimension of visual culture. One interesting aspect of this growing art theoretical interest in Warburg's notion of Pathosformel is that it historicises gesture within visual culture, suggesting that images are central to storing and transmitting languages of gesture, rather than merely reflecting a universalist idea of body language. Warburg's Mnemosyne Atlas identifies the visual tropes of gesture, emotion and expression through comparison and generalisation. ${ }^{81}$ Quilty's Captain S after Afghanistan takes the pose of Dürer's Orpheus, vertically flips and then rotates it $90^{\circ}$ clockwise. So, while the semi-abstraction of Quilty's painting enacts a traumatic inarticulation, its figuration draws on a gestural trope of suffering that has its origins in ancient Greece. ${ }^{82}$ 


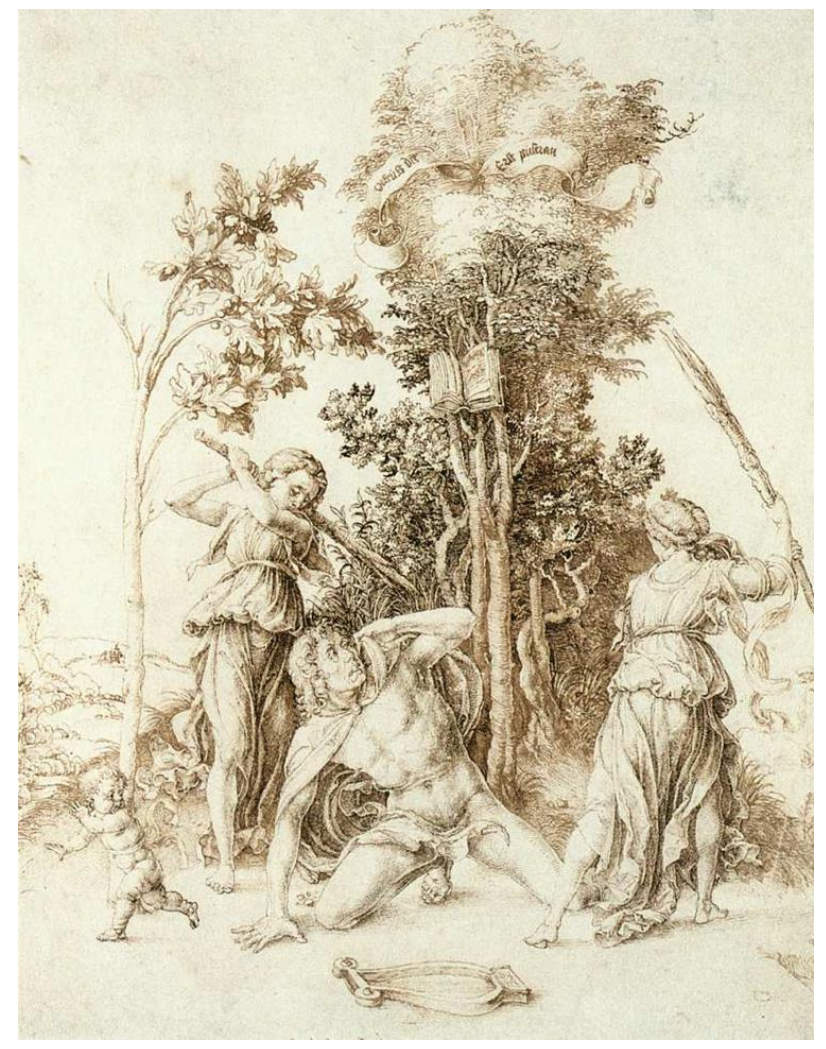

Figure 9. Albrecht Dürer, The Death of Orpheus, 1494, pen and ink on paper, $28.9 \mathrm{~cm} \times 22.5 \mathrm{~cm}$. Image courtesy of Hamburger Kunsthalle.

\section{Conclusion}

Butler's suggestion is certainly accurate-the more direct political pronouncements made on behalf of these works, the claims for what they represent, are not borne out in the works themselves, at least not in any straightforward representational register. However, I disagree with Butler's wider dismissal of the works as articulating little more than an 'empty expressiveness' ${ }^{83}$ Rather, Quilty's portraits become animated on the aesthetic level-in the fragmentation of their subjects, caught in a compromised state of aesthetic unbecoming. In turn, the semi-abstraction of their subjects' bodies, combined with gestural tropes found in their figurative elements, is amplified in its resonance at the representational level, as naked portraits of soldiers, which layers the bodies of private citizens with that of being political subjects of the state. However, the well-meaning clamour surrounding the canvases overwhelms the political aesthetics of these paintings, rendering them difficult to discern, and 
then speaking on their behalf. The mass-mediated utterances, in the multiple news stories, articles, documentaries, the reiterative articles, interviews and reviews, so thoroughly weave throughout the interpretative layers of these portraits that what Jacques Rancière calls 'metapolitics ${ }^{84}$ becomes enmeshed within a contemporary macro-political milieu, thickening into an earnest and overcommitted political 'message'. At the centre of this maelstrom, it is understandable that these works could be read as empty, the eye of the mass media storm; however, to do so misses the opportunity to go a step further into the meta-political realm at which the politics of aesthetics operates, which overthrows the representational regime.

Certainly, Quilty's work as Australian Official War Artist is ripe for closer critical consideration, particularly because, as Butler points out, his work has enjoyed broad and often uncritical acceptance, which has in turn amplified certain interpretations of his work well beyond what the works actually show. Quilty's work moreover has become too significant in Australia to either dismiss or accept without interrogation. Indeed, more broadly, the provocation of Quilty's frequent championing of painting itself, its 'resurrection', 85 within its potentially problematic broader economic and institutional contexts has gone largely unmet; despite, perhaps, it underlying a certain degree of the critical disquiet surrounding his work more generally. By no means does this article seek to defend Quilty's works, but in its approach it seeks to 'accept the offer' (as they say in improvisational theatre) of their aesthetic statements before considering what they address and the ways in which they do so. Indeed, this article forms a small part of a larger endeavour to consider the role of aesthetics and politics in images of, and surrounding, violent conflict. To understand the politics of war images within contemporary art, it is necessary to challenge a persistent assumption that aesthetics and politics are mutually exclusive, an aesthetics-versus-politics formulation that still dominates contemporary debate about war art. Rather, it is necessary to consider the complex ways in which politics operate through the aesthetic realm in works such as Quilty's After Afghanistan portraits. While it is vital to understand art works within their contexts, it is valuable to return to the work itself, to engage it within what Jill Bennett calls a 'practical aesthetics', which recognises the 'affective and social relations, events and object-making' that converge in the visual. ${ }^{86}$ The stakes are high in understanding contemporary visual culture surrounding violent 
conflict. Audiences see images of political violence quite unlike those seen in the past, visual by design, for immediacy in news and social media-the 2014 spate of ISIS execution videos distributed on the internet; the 2014 Lindt Café siege, staged opposite Channel 7's studios in Martin Place, Sydney, arguably to ensure maximum media coverage; video images of the 2015 attacks on Paris, or Nice and Berlin in 2016, or Stockholm, Manchester, and multiple attacks in London in 2017, are captured by CCTV cameras, dashcams and smartphones and distributed almost immediately via online news, social media and television. Amongst this milieu of massmediated representations of violence, contemporary war art has the capacity to disrupt or suspend the immediate and reactive reception of emotionally-charged media images of war. Through closer consideration of the meta-politics of aesthetics within contemporary war art, we might better understand how mediated images of war and political violence today shape how we, the audience and consumers of these images, think about war.

\footnotetext{
${ }^{1}$ The term 'official war artist' is intended as a generic term across different official programs. Where this article refers to 'Official War Artist' as a proper noun, it pertains to the Australian Official War Artist program.

${ }^{2}$ Catherine Speck, 'The Australian War Museum, Women Artists and the National Memory of the First World War', When the Soldiers Return: November 2007 Conference Proceedings, ed. Martin Crotty (Brisbane: School of History, Philosophy, Religion and Classics, University of Queensland, 2009), 278.

${ }^{3}$ Laura Brandon, Art \& War (London: IB Taurus, 2009), 103.

${ }^{4}$ Ryan Johnston, 'Recalling History to Duty: 100 years of Australian war art', Artlink 35, no. 1 (March 2015 ): 12.

${ }^{5}$ Susan Cahill, 'The Art of War: Painted Photographs and Australia's "War on Terror"', RACAR: revue d'art canadienne 39, no. 2 (2014): 74.

${ }^{6}$ Johnston, 'Recalling History to Duty', 12.

${ }^{7}$ Ibid., 15.

8 Ibid., 16.

${ }^{9}$ Department of Defence, 'Vale', http://www.defence.gov.au/vale/ (accessed 8 June 2017).

${ }^{10}$ Ben Quilty, quoted in Laura Webster, 'After Aghanistan', Ben Quilty: After Afghanistan, curated by Laura Webster (Canberra: Australian War Memorial, 2013), 8.

${ }^{11}$ Ben Quilty, in Kit Messham-Muir, 'Interview with Ben Quilty, artist, Robertson, Australia, 26 January 2013', StudioCrasher (7 February 2013), https://www.youtube.com/watch?v=j606Xg1j8zs\&t=3238s.

12 Ibid.

${ }^{13}$ Craig Reucassel, 'On the Warpath-Transcript: Monday, 25 March, 2013', http://www.abc.net.au/austory/content/2012/s3723112.htm (accessed 7 June 2017).

${ }^{14}$ Ben Quilty, 'The Art of War', public gallery panel discussion, Cell Block Theatre, National Art School, Sydney, 2013.

${ }^{15}$ Ben Quilty, in Reucassel, 'On The Warpath'.

16 Ibid.

${ }^{17}$ Rex Butler, 'Ben Quilty: The Fog of War', Finest Art Seminar Series Tonight (FASST), Inaugural Seminar 14 April 2015, Part II, Panoptic Press (24 June 2015), https://www.youtube.com/watch?v=dr3ie4DT1qg (accessed 26 May 2017).
} 
${ }^{18}$ Rex Butler, 'Ben Quilty: The Fog of War', Intellectual History Review 27:3 (2017): 433-451. While the seminar paper (2015) and the journal article are substantially similar, there are some notable differences between the two versions, which are noted specifically where relevant.

19 Ibid., 434.

20 Ibid., 438.

${ }^{21}$ Butler, 'Ben Quilty', 2015.

22 Butler, 'Ben Quilty', 2017: 438.

23 Ibid., 439.

24 Ibid.

25 Ibid., 443.

26 Ibid.

27 Ibid.

${ }^{28}$ Butler, 'Ben Quilty', 2015.

29 Ibid.

${ }^{30}$ Butler, 'Ben Quilty, 2017: 449.

31 lbid., 442.

32 Quilty, in Reucassel, 'On The Warpath'.

33 Julian Stallabrass, 'Traces of War Symposium', panel discussion, Kings College London, 1 October 2016.

${ }^{34}$ Butler, 'Ben Quilty', 2015.

${ }^{35}$ Quilty, 'The Art of War'.

${ }^{36}$ Johnston, 'Recalling History to Duty', 15.

${ }^{37}$ Quilty, 'The Art of War'.

${ }^{38}$ Adrian Searle, 'Last Post', The Guardian, 13 March 2007, https://www.theguardian.com/politics/2007/mar/12/iraq.art (accessed 25 May 2017).

${ }^{39}$ Shaun Gladwell, interview with Kit Messham-Muir, Paddington, Sydney, 26 April 2010, transcribed by Susan Cairns.

${ }^{40}$ Darren Jorgensen, 'George Gittoes and the Social Turn in Afghanistan', Artlink 36, no. 1 (March 2016 ): 27.

41 Ibid.

42 Julian Stallabrass, 'The Power and Impotence of Images', Memory of Fire: The War of Images and Images of War, (Brighton: Brighton Photo Biennial, 2008), 5.

${ }^{43}$ Quilty, 'The Art of War'.

${ }^{44}$ Stallabrass, 'The Power and Impotence of Images,' 6

45 Ibid., 5.

46 Ibid., 6.

${ }^{47}$ Shaun Gladwell, interview with Kit Messham-Muir, Hyde Park, London, 30 September 2010, transcribed by Susan Cairns.

48 Ibid.

${ }^{49}$ Cahill, 'The Art of War', 77.

50 Quilty, 'The Art of War'.

${ }^{51}$ Gladwell, interview with Messham-Muir, 2010.

${ }^{52}$ Cahill, 'The Art of War', 77.

53 Lyndell Brown, Jon Cattapan, and Charles Green, Framing Conflict: Contemporary War and Aftermath (South Yarra: Palgrave Macmillan, 2014), 50.

${ }^{54}$ Butler, 'Ben Quilty', 2017, 443.

${ }^{55}$ Laura Webster, 'After Aghanistan', Ben Quilty: After Afghanistan (Canberra: Australian War Memorial, 2013 ), 20.

${ }^{56}$ Makani Luske, 'A Soldier's Mirror', Write About Art 5 (2015), http://www.eyelinepublishing.com/write-about-art5/article/soldiers-mirror (accessed 9 June 2017).

57 John McDonald, 'Soldiers Laid Bare', The Sydney Morning Herald, 9 March 2013, http://www.smh.com.au/entertainment/art-and-design/soldiers-laid-bare-20130306-2flim.html (accessed 20 June 2017).

${ }^{58}$ Art Gallery of New South Wales, 'Ben Quilty', Archibald Prize 2012, https://www.artgallery.nsw.gov.au/prizes/archibald/2012/29238/ (accessed 30 May 2017). 
${ }^{59}$ Captain S, in Craig Reucassel, 'War Paint-Transcript. Program Transcript: Monday, 3 September, 2012', http://www.abc.net.au/austory/content/2012/s3581736.htm (accessed 30 May 2017).

${ }^{60}$ Art Gallery of New South Wales, 'Ben Quilty'.

$61 \mathrm{lbid}$.

${ }^{62}$ Kathryn Robinson, 'Interview with Ben Quilty and Kate Porter: Meet the Press interviews Australian artist Ben Quilty and his subject Australian Army Captain Kate Porter about their experiences working together', Meet the Press, 24 February (Melbourne: TEN, 2013),

http://search.informit.com.au.dbgw.lis.curtin.edu.au/documentSummary; dn=TEV20130902101;res=TVNEWS (accessed 15 June 2017).

${ }^{63}$ Andrew Yip, 'Gender War: Shaun Gladwell and Ben Quilty in Afghanistan', Artlink 33, no. 3 (September 2013), https://www.artlink.com.au/articles/4008/gender-war-shaun-gladwell-and-ben-quilty-in-afgha/ (accessed 30 May 2017).

${ }^{64}$ Butler, 'Ben Quilty', 2017, 445.

${ }^{65}$ Brendon Nelson, 'Foreword', Ben Quilty: After Afghanistan (Canberra: Australian War Memorial, 2013$), 5$.

${ }^{66}$ Vlad Ionescu, 'On Moths and Butterflies, or How to Orient Oneself through Images. Georges-Didi Huberman's Art Criticism in Context', Journal of Art Historiography 16 (June 2017): 2-3.

${ }^{67}$ Butler, 'Ben Quilty', 2017, 449.

$68 \mathrm{Ibid}, 446$.

69 lbid.

${ }^{70}$ Ibid., 446-447.

${ }^{71}$ Ibid., 447, 450.

${ }^{72}$ Butler, 'Ben Quilty', 2015.

${ }^{73}$ Yip, 'Gender War'.

${ }^{74}$ Aby Warburg, 'Durer and Italian Antiquity', The Renewal of Pagan Antiquity: contributions to the cultural history of the European Renaissance, trans. David Britt (Los Angeles: Getty Research Institute for the History of Art and the Humanities, 1999), 553-558.

75 Ibid., 553

${ }^{76}$ See Jane O. Newman and Laura Hatch, 'Panel 70', Mnemosyne: Meanderings through Aby Warburg's Atlas, https://warburg.library.cornell.edu/image-group/panel-70-sequence-3-part-1-4 (accessed 23 June 2017).

77 Sarah Angel, 'The Mnemosyne Atlas and the Meaning of Panel 79 in Aby Warburg's Oeuvre as a Distributed Object', Leonardo 44, no. 3 (2011): 266.

${ }^{78}$ Colleen Becker, 'Aby Warburg's Pathosformel as Methodological Paradigm', Journal of Art Historiography 9 (December 2013): 2.

${ }^{79}$ Georgio Agamben, Potentialities: Collected Essays on Philosophy (Stanford: Stanford University Press, 1999), 90.

${ }^{80}$ Becker, 'Aby Warburg's Pathosformel as Methodological Paradigm', 2.

${ }^{81}$ Interestingly, Leonardo Impett and Sabine Susstrunk recently took this one step further and applied a computational cluster analysis of the angles of limbs in body poses of 318 images in Warburg's Mnemosyne Atlas, around a quarter of its total images, and concluded that 'Pathosformeln can sometimes be characterised entirely by body pose', ignoring facial affective cues. Leonardo Impett and Sabine Susstrunk, 'Pose and Pathosformel in Aby Warburg's Bilderatlas', in Computer Vision-ECCV 2016 Workshops, Part I, LNCS 9913, ed. Gang Hua and Hervé Jégou (Cham, Switzerland: Springer, 2016), 900.

${ }^{82}$ Warburg, 'Durer and Italian Antiquity', 553.

${ }^{83}$ Butler, 'Ben Quilty', 2017, 443.

${ }^{84}$ Jacques Rancière, The Politics of Aesthetics (London: Continuum, 2004), 60.

85 Jan Murphy Gallery, 'Ben Quilty', http://www.janmurphygallery.com.au/wpcontent/uploads/2013/09/QUI_CV1.pdf (accessed 16 October 2017).

${ }^{86}$ Jill Bennett, Practical Aesthetics: Events, Affects and Art after 9/11 (London: IB Taurus, 2012), 15. 